\title{
SACCHARIFICATION OF CORNCOB USING CELLULOLYTIC BACTERIA FOR BIOETHANOL PRODUCTION
}

\author{
TITI CANDRA SUNARTI ${ }^{1}$, ANJA MERYANDINI ${ }^{2}$, M. EDY SOFIYANTO' \\ and NUR RICHANA \\ ${ }^{1}$ Department of Agroindustrial Technology, Faculty of Agricultural Engineering and Technology, Bogor \\ Agriculture University, Bogor, Indonesia \\ ${ }^{2}$ Department of Biology, Faculty of Mathematics and Natural Sciences, Bogor Agriculture \\ University, Bogor, Indonesia \\ ${ }^{3}$ Research Institute for Agricultural Postharvest, Ministry of Agriculture, Bogor, Indonesia
}

Recipient of BIOTROP Research Grant 2008 / Accepted 10 August 2010

\begin{abstract}
The use of cellulose degrading enzyme (cellulases) for hydrolysis of lignocellulosic material is a part of bioethanol production process. In this experiment, delignified corncob, its cellulose fraction and alpha cellulose were used as substrates to produce fermentable sugar by using three local isolates of celluloytic bacteria (C5-1, C4-4, C11-1 and Cmix ; mixed cultures of three isolates), and Saccharomyces cereviseae to produce ethanol. The results showed that all isolates of cellulolytic bacteria can grow on cellulose fraction better than on delignified corncob and alpha cellulose. The highest hydrolytic activity produced from cellulose fraction was by isolate C4-4, which liberated $3.50 \mathrm{~g} / \mathrm{l}$ of total sugar. Ethanol can be produced by mixed culture of bacteria and yeast, but because of competitive growth, the fermentation only produced $0.39-0.47 \mathrm{~g} / \mathrm{l}$ of ethanol.
\end{abstract}

Keywords: Celluloses, delignified corncob

\section{INTRODUCTION}

The cost of raw materials, such as sugar and corn starch, is a limiting factor in the production of bio-ethanol. At the same time, there is a large amount of agricultural residue as well as agro-industrial by-products which sometimes needs disposal process cost if it is not used.

Corn is the second major source of carbohydrates for Indonesia used especially for feed and industrial raw materials. Most corn is used as raw material for food and non-food industries. These applications are limited to the corn kernel, while other parts of corn plant are not utilized. About 30\% of the corn consists of corncob with

\footnotetext{
*Corresponding author : titi-cs@ipb.ac.id
} 
abundant lignocellulosic raw materials which are a potential source for fuel ethanol production in Indonesia.

From our previous research (Meryandini et al. 2008), we tried to extract xylan from corncobs. A large amount of waste corncob residue (as cellulose fraction) was produced in the xylan extraction. It is an important issue to deal with the residue both for the comprehensive utilization of lignocellulosic resources and for the prevention of environmental pollution. Since most of the hemicellulose in corncob has been extracted into xylan, the corncob residue is porous and easy to degrade by cellulolytic bacteria. In this work corncob residue with a simple pretreatment is being used as a substrate to produce glucose by cellulase-producing bacteria isolated from West Java from our previous research (Maranatha 2008), and the ethanol production conducted by two successive microbial processes using mixed culture of cellulolityc bacteria and Saccharomyces cerevisiae.

\section{MATERIALS AND METHODS}

\section{Preparation of raw materials}

Corncob from local hybrid variety (Golden variety) was provided from local supplier at Leuwi Kopo, Bogor. The corncob was dried and ground then used as grits (about 40 mesh). The chemical composition was analyzed as proximate analysis (moisture, protein, lipid, carbohydrate, ash and crude fibers contents; using AOAC (1984) method), and cellulose, hemicellulose and lignin contents (van Soest 1963).

\section{Preparation of corncob substrates}

The corncobs were delignified and the cellulose fraction isolated according to Richana et al. (2007) and Sunarti and Richana (2008). Alpha-cellulose was prepared according to Xiang et al. (2003) method by soaking in $45 \% \mathrm{H}_{2} \mathrm{SO}_{4}$ for 4 hours. All substrates were analysed for the fiber components according to Van Soest (1963) methods.

\section{Preparation of cultures and enzymes}

Yeast Saccharomyces cerevisiae was obtained from the collection of Bioindustry Laboratory of IPB, while local isolates of aerobic cellulolytic bacteria were supplied by the Laboratory of Animal Biotechnology and Biomedics, Research Center for Bioresources and Biotechnology of IPB. The yeast was cultured on PDA (Potato Dextrose Agar), and for starter preparation the fresh culture was inoculated on PDB (Potato Dextrose Broth) and incubated on $120 \mathrm{rpm}$ of agitation speed, $30^{\circ} \mathrm{C}$ for 24 hours. The cellulolytic bacteria were grown on 1\% of CMC-agar, and in CMC-broth for cellulolytic enzyme preparation, incubated at $30^{\circ} \mathrm{C}$ and $120 \mathrm{rpm}$ of agitation speed for 48 hours. 


\section{Bacterial hydrolysis of corncob substrates}

Hydrolysis of corncob substrates were determined by using three local bacterial isolates (C4-4, C11-1, C5-1), and Cmix of all mixed isolates grown in 1\% of delignified corncob (S1), cellulose fraction (S2), pretreated cellulose fraction (alpha cellulose, S3) as substrates at $30^{\circ} \mathrm{C}$ and $\mathrm{pH} 5$ for 48 hours. The products of enzymatic hydrolysis were calculated as total soluble sugar (Dubois et al. 1956). Enzyme assays as Filter paperase (FP-ase), Carboxylmethylcellulase (CMC-ase) and Xylanase activities were examined based on total reducing sugar produced and determined using DNS method (Miller 1959) and specific activity of each enzyme was calculated according to the protein concentration (Bradford 1976).

\section{Ethanol production}

Ethanol production was conducted using mixed cultures of cellulolytic bacteria and Sacharomyces. One percent of cellulose fraction in $500 \mathrm{ml}$ of Erlenmeyer flask was used as substrate, and hydrolyzed with the enzymes, then used as fermentation substrate enriched with $0.04 \%$ of NPK and $0.15 \%$ of ZA fertilizers. Inoculation time for yeast starter is determined at the final stage of exponential phase (P1, 20 hours), and initial stage of stationer phase (P2, 32 hours) of cellullolytic bacteria growths. Fermentation was conducted under closed system without aeration. The design of the fermentation apparatus was as shown in Figure 1. The reactor was incubated on room temperature $\left(28^{\circ} \mathrm{C}\right)$ and $120 \mathrm{rpm}$ of shaker agitation speed. $\mathrm{CO}_{2}$ liberated from the system was measured and calculated as gas formation rate for every 6 hours. Ethanol concentration was determined using Gas Chromatography.

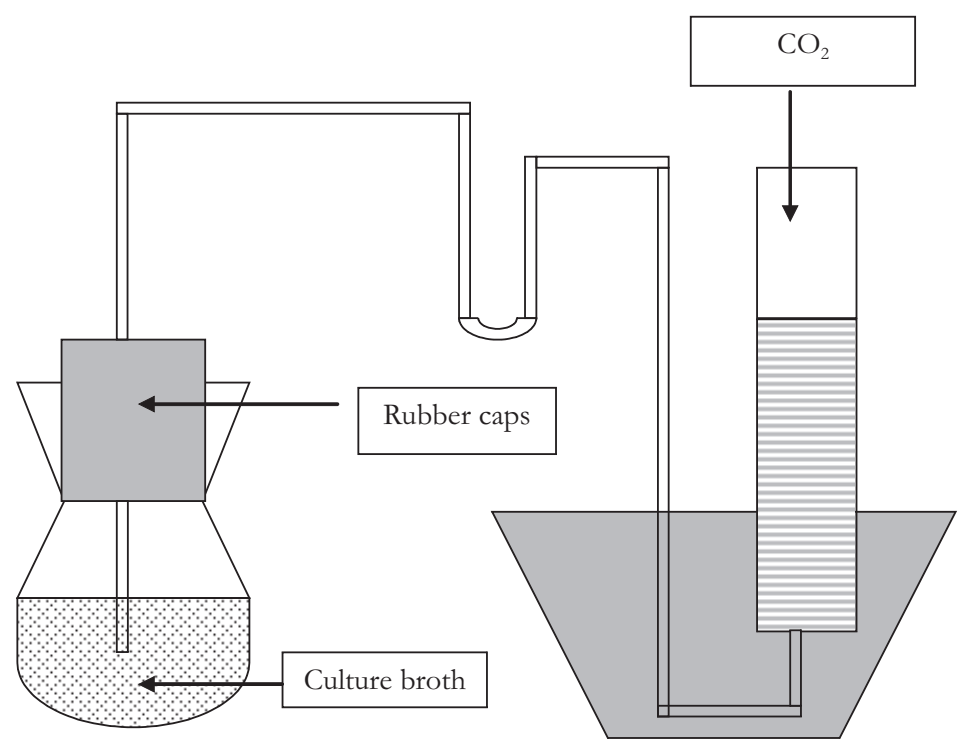

Figure 1. Ethanol fermentation apparatus 


\section{RESULTS AND DISCUSSIONS}

\section{Substrates characterization}

Corncobs consisted mainly of carbohydrate (55.89\%) and crude fiber (39.5\%). Pretreatment was conducted using several steps, as size reduction, delignification, cellulose recovery and preparation of alpha cellulose. These processes will degrade the materials and be more susceptible to cellulolytic enzyme to hydrolyze the cellulose. Pretreatment also eliminated the materials such as lignin. According to Foody et al. (1999), pretreatment can be combined between physical treatments, such as milling, pressurized treatment, and pressing, and chemical treatments such as steam, solvent and acid treatments.

Degradation of cellulose molecules is limited by the high degree of polymerization, its crystalline molecular structure, and lignin component which covered the cellulose molecules (Chang et al. 1981). The amounts and composition of cellulose, hemicellulose and lignin on corncob varied between pre- and postdelignification as shown in Table 1. Delignification improves the enzyme action during cellulose hydrolysis.

Table 1. Fiber compositions of corncob, delignified corncob, cellulose fraction and alpha cellulose

\begin{tabular}{lcccc}
\hline Constituent & $\begin{array}{c}\text { Corncob } \\
(\% \mathrm{dm} *)\end{array}$ & $\begin{array}{c}\text { Delignified } \\
\text { corncob } \\
(\% \mathrm{dm})\end{array}$ & $\begin{array}{c}\text { Cellulose fraction } \\
(\% \mathrm{dm} *)\end{array}$ & $\begin{array}{c}\text { Alpha cellulose } \\
(\% \mathrm{dm} *)\end{array}$ \\
\hline Cellulose & 37.44 & 21.73 & 77.08 & 68.44 \\
Hemicellulose & 39.81 & 32.73 & 11.98 & 6.22 \\
Lignin & 12.57 & 11.25 & 7.52 & \\
\hline
\end{tabular}

Note : *dry matter, the measurement after the moisture removed

Table 1 shows significantly the differences between cellulose fraction before and after delignification. Recovery of cellulose increased the purity of substrate up $77 \%$ of cellulose. $\mathrm{NaOH}$ is used in solubilization of hemicellulose. Cellulose fraction was transformed into amorphous form by soaking $\mathrm{H}_{2} \mathrm{SO}_{4}$. According to Xiang et al. (2003), cellulose suspended on $\mathrm{H}_{2} \mathrm{SO}_{4} 65 \%$ will change into amorphous structures. In the present study, high concentration of $65 \% \mathrm{H}_{2} \mathrm{SO}_{4}$ made cellulose burn, so we use $45 \%$ of $\mathrm{H}_{2} \mathrm{SO}_{4}$ solution. Microscopic structure of each substrate is shown on Figure 2. 


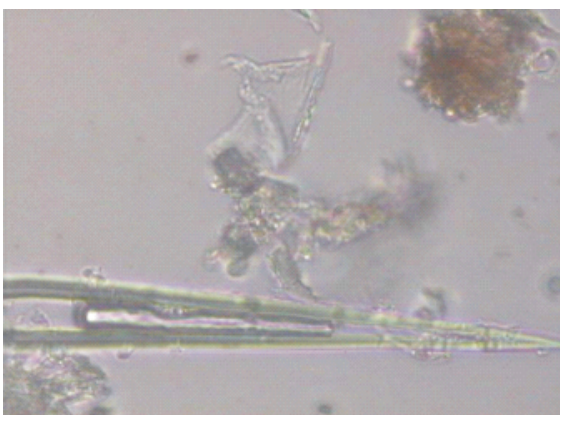

(a)

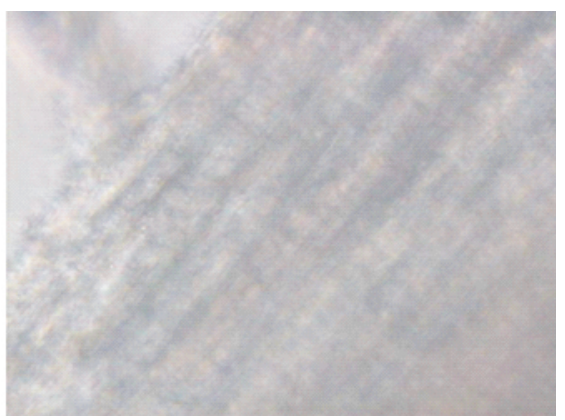

(c)

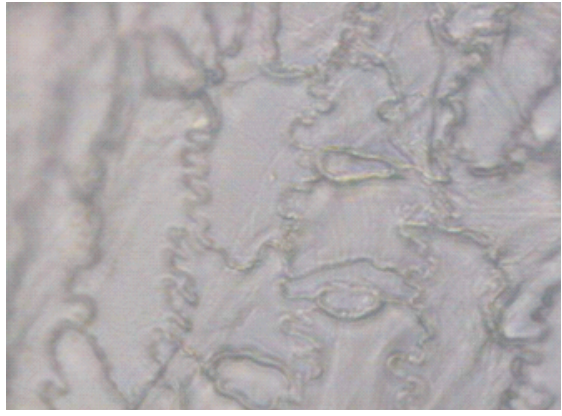

(b)

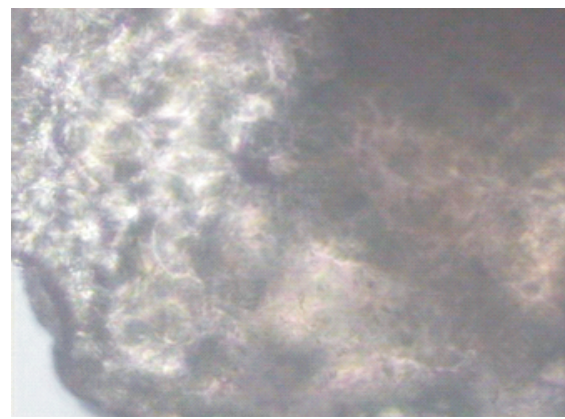

(d)

Figure 2. Microscopic structures of (a) corncob, (b) delignified corncob, (c) cellulose fraction, (d) alpha cellulose using light microscope (400x magnification).

Delignification of corncob caused shrinking of fiber as shown in the microscopic structure of delignified corncob (Fig. 2(b)). After removing the hemicellulose, most of the cellucose fraction lost its integrity and crystallinity (Fig. 2(c)), and then transformed into more amourphous cellulose (Fig. 2(d)).

\section{Saccharification of corncob by cellulolytic bacteria}

Cellulolytic bacteria will release cellulases, complexes of cellulolytic enzymes if grown in cellulose substrates. According to Kim (1995), cellulase enzyme is multienzymes system consists of endo-1,4- $\beta$-glucanase, exo-1,4- $\beta$-glucanase, and $\beta$ D-glucanase. The glucoside bound in cellulose will be broken down randomly by endo-1,4- $\beta$-glucanase to produce short cellulose chains, exo-1,4- $\beta$-glucanase liberates cellobiose, while $\beta$-D-glucosidase will hydrolyse cellobiose into two molecules of glucose.

Each microorganism releases its unique cellulase complex; depending on the gene and carbon sources. In this research, four isolates, C11-1, C4-4, C5-3 and Cmix (mixed cultures of three isolates) are grown on 4 types of substrates. Total soluble sugars as products of hydrolysis are released and shown in Figure 3. 
All bacteria strains can grow on all corncob substrates, but Figure 3(a) showed that the influence of remained lignin on delignified corncob cause low growth of bacteria. Lignin will suppress the enzyme access to degrade polysaccharide and caused low enzyme performance during saccharification (Sun \& Cheng 2002). Figure 3(c) showed the absence of saccharification activity of bacteria on alpha cellulose substrate, and it may be caused by high furfural compound, produced from solubilization of cellulose using $\mathrm{H}_{2} \mathrm{SO}_{4}$, and inhibited bacterial growth (Taherzadeh 1999). Figure 3 (b) shows saccharification process on cellulose fraction, and exhibits normal growth of bacteria, and produced soluble sugars. By using cellulose fraction as substrates, all bacteria can grow and breakdown the cellulose matrix as shown in Figure 4.

High hydrolytic activity is gained from isolate C4-4 and grown on cellulose fraction, compared to other isolates and substrates. The enzymatic activity of C4-4 culture was examined on several substrates and shown in Table 2, such as FP-ase, CMC-ase (amorphous cellulose) and xylanase. Local isolate C4-4 is able to hydrolyze the complex substrate of cellulose fraction which contained small amounts of hemicellulose and trace amount of lignin. Changes on microscopic structure of cellulose fraction can be compared from Figure 2(c) and Figure 4. It showed the real degradation of cellulose before and after enzyme attack action during bacterial saccharification by isolate $\mathrm{C} 4-4$.

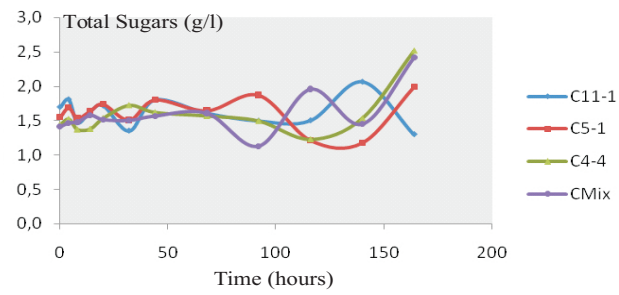

(a)

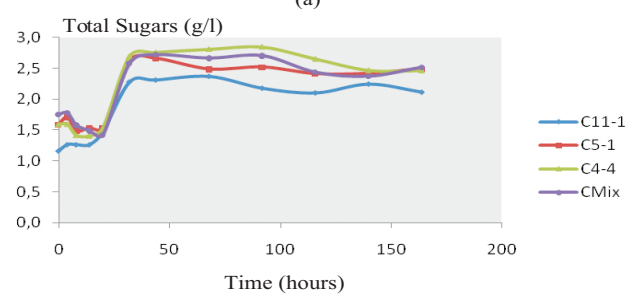

(b)

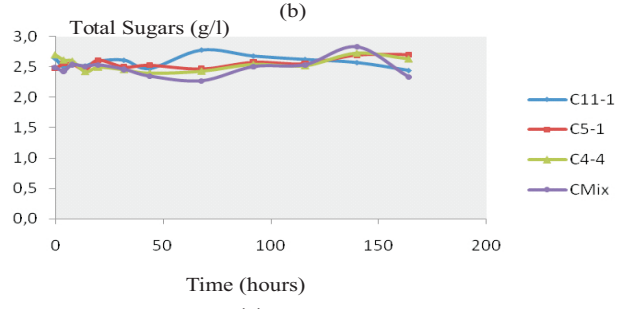

(c)

Figure 3. Time courses of hydrolysis of substrates (a) delignified corncob, (b) cellulose fraction, (c) alpha cellulose by several local bacteria isolates 

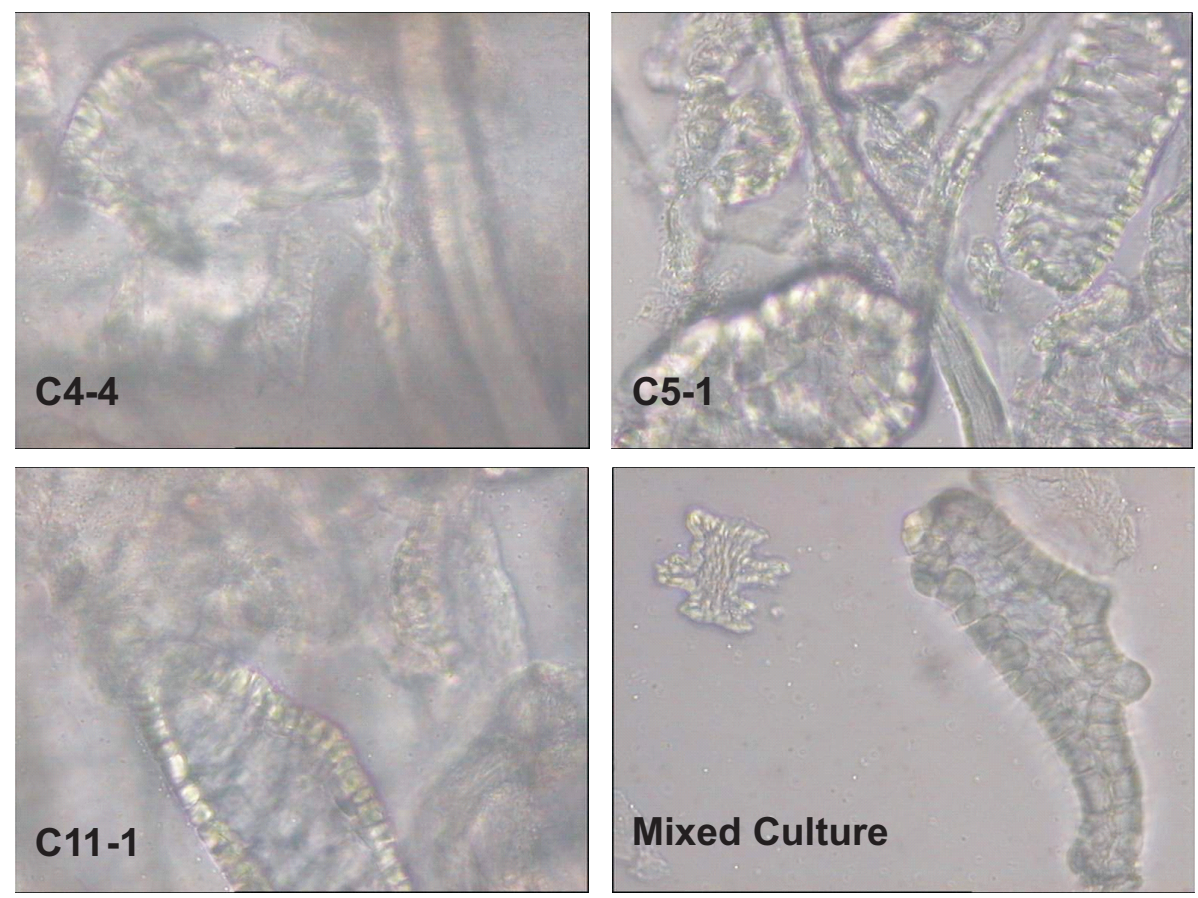

Figure 4. Microscopic structure of cellulose fraction after 164 hours hydrolysis by several bacterial isolates (Light microscope, $400 \mathrm{x}$ magnification)

Table 2. Enzyme activities of isolate C4-4 on several substrates

\begin{tabular}{lcc}
\hline \multicolumn{1}{c}{ Substrates } & $\begin{array}{c}\text { Activity } \\
\text { (nkat/ml) } \times 10^{-3}\end{array}$ & Specific Activity (nkat/mg) $\times 10^{-3}$ \\
\hline CMC (funix) & 35.2 & 106.67 \\
Filter paper & 39.5 & 119.70 \\
Xylan & 57.9 & 175.45 \\
Corncob flour & 81.0 & 245.45 \\
\hline
\end{tabular}

Note : *Maranatha (2008)

\section{Ethanol production using mixed cultures of bacteria and yeast}

Ethanol is one of the products of fermentation products with simple sugar as the main substrate. Yeast, is a microorganism that ferments glucose into ethanol. According to Ratledge (1991), yeast from S. cerevisiae is commonly used in hexose fermentation. Saccharomyces cerevisiae can produce ethanol from glucose and mannose in high sugar concentration and anaerobic condition.

Ethanol is a products of fermentation product produced during the stationary phase. Some parameters can be indicators of ethanol formation, such as $\mathrm{CO}_{2}$ production. This research also investigated the inoculation time of yeast starter during mixed culture fermentation, after 20 hours (P1) and 32 hours (P2) of bacterial growth 
time. After 20 hours, microorganism is on the final stage of exponential phase and maximum growth activity, while after 32 hours, it is on the initial stage of stationery phase and the bacterial activity decreased.

Based on Figure 5, the formation of $\mathrm{CO}_{2}$ fluctuated during the fermentation activity. As inoculation of yeast was conducted without bacteria sterilization, the fermentation was conducted as synergistic action between bacteria and yeast. Bacteria produced simple sugars, which were used for biomass formation and ethanol production. Those process resulted in carbon dioxide as by-product of fermentation. High rate of $\mathrm{CO}_{2}$ formation conducted after 6 hours of inoculation time using P2 system. According to Taherzadeh (1999), the optimal fermentation rate happened after 4-6 hours of fermentation. About 10\% of inoculums and high concentration of sugar in culture from saccharification made $S$. cerevisiae show higher activity. During fermentation, competitive carbon source utilization usually happens during multiorganisms activity. Bacteria and yeast use glucose for growth, and yeast uses glucose to produce ethanol. The lack of glucose will induce cellulase to degrade cellulose and liberate glucose.

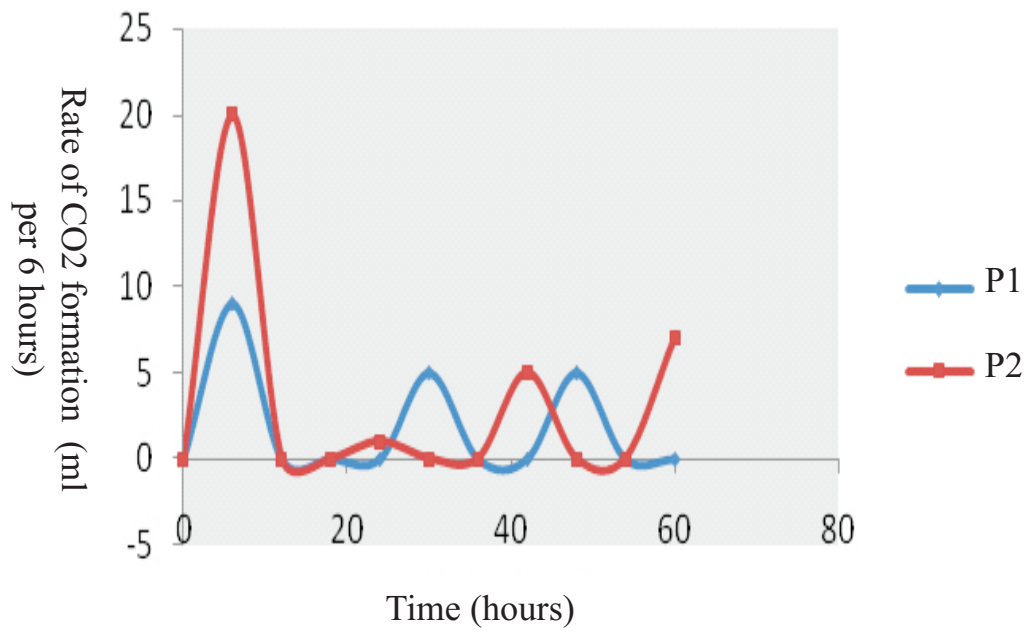

Figure 5. Rate of $\mathrm{CO}_{2}$ formation during fermentation for different yeast inoculation time. 
Ethanol produced from different inoculation time shows different yields, as 0,39 $\mathrm{g} / 1$ for P1 and 0,47 g/l for P2. This amount is very small, due to the low availability of fermentable sugars. Cellulose as substrate for saccharification is converted from crystalline form to amorphous one, then degraded into more soluble amorphous form and then few are completely depolymerized into simple sugars. Microscopic observation of Figure 4 proved that softened cellulose is amorphous cellulose, but not soluble cellulose. The bacteria have to convert it into simple sugars (glucose) which can be used for yeast to produce ethanol.

Based on Table 3, the amount of bacteria increased but not yeast. Suppression of yeast growth might be caused by low sugar concentration which influence ethanol production. Initial concentration of bacteria was $23 \times 10^{8}$ and increased ten times at the end of fermentation, but yeast concentration decreased per tenth finally.

Table 3. Quantification of Microorganism during Fermentation

\begin{tabular}{lcc}
\multicolumn{1}{c}{ Stage of Fermentation } & $\begin{array}{c}\text { Total Plate Count } \\
(\text { colony } / \mathrm{ml})\end{array}$ & $\begin{array}{c}\text { Total Yeast } \\
(\text { colony } / \mathrm{ml})\end{array}$ \\
\hline Initial stage & $23 \times 10^{8}$ & $41 \times 10^{7}$ \\
\hline Final Stage & & \\
\hline After 20 hours (P1) & $25 \times 10^{9}$ & $51 \times 10^{6}$ \\
After 32 hours (P2) & $20 \times 10^{9}$ & $58 \times 10^{6}$ \\
\hline
\end{tabular}

Beside ethanol, fermentation also liberated organic acid as by-products. Since organic acids are intermediate products during glucose metabolism through Embeden Meyerhouf-Parnas pathway, the acid should be suppressed during ethanol fermentation, because influenced to the reduction of ethanol yields. Available oxygen also should be minimized to reduce the oxidative metabolism of pyruvic acid into tricarboxylic acids.

\section{CONCLUSIONS}

Corncob can be used as carbon sources for ethanol fermentation after hydrolysis into simple sugar first. Pretreatments are needed to improve the saccharification process of cellulose. All isolates of cellulolytic bacteria can grow on cellulose fraction better than on delignified corncob, and alpha cellulose. The highest hydrolytic activity was observed with cellulose fraction and isolate C4-4, which liberated $3.50 \mathrm{~g} / 1$ of total sugar.

Ethanol can be produced by mixed culture fermentation of bacteria and yeast. But since it caused a competitive growth which influenced the productivity, fermentation activity only produced $0.39-0.47 \mathrm{~g} / \mathrm{l}$ of ethanol. 


\section{ACKNOWLEDGEMENTS}

This research was funded by DIPA Satuan Kerja Pusat Studi Regional Penelitian Biologi Tropika (SEAMEO BIOTROP) with contract agreement No. 047.1/PSRPSP/III/2008 to Titi Candra Sunarti.

\section{REFERENCES}

AOAC. 1984. Official Methods Analysis The Association of Official Analytical Chemist. $14^{\text {th }}$ ed. AOAC, Inc. Arlington. Virginia.

Bradford M.M. 1976. A rapid and sensitive for the quantification of microgram quantities of protein utilizing the principle of protein-dye binding. Analytical Biochemistry, 72: 248-254.

Chang M.M., Chon T.C. and G.T. Tsao. 1981. Structure Pretreatment and Hydrolysis Cellulose. Advance Biochemical Engineering, 20:14-25.

Dubois M., Gilles K.A., Hamilton J.K., Rebers P.A. and F. Smith. 1956. Colorimetric Method for Determination of Sugar and Related Substances. Analytical Chemistry, 28(3):350-356.

Foody B.J., Tohan S. and J.D. Bernstein. 1999. Pretreatment Process for Conversion of Cellulose to Fuel Ethanol. U.S. pat. No. 6.090.595.

Kim H. 1995. Characterization and Substrate Specivicity of an Endo-Beta-1,4-D-Glucanase (Avicelase I) from An Extracelluler Multienzyme Complex of Bacillus circulans. Applied Environment and Microbiology, 61:959-965.

Maranatha B. 2008. Aktivitas Ensim Selulase Isolat Asal Indonesia pada Berbagai Substrat Limbah Pertanian.Undergraduate thesis (skripsi). FMIPA IPB.

Meryandini A., Sunarti T.C., Naomi A. and F. Mutia. 2008. Using Streptomyces Xylanase to Produce Xylooligosaccharide from Corncob. Biotropia, 15(2):119-128.

Miller G.L. 1959. Use of Dinitrosalicyclic Acid Reagent for Determination of Reducing Sugar. Analytical Chemistry, 31: 426-428.

Ratledge C. 1991. Yeast Physiology - a Micro-synopsis. Bioprocess Engineering, 6:195-203.

Richana N., Irawadi T.T., Nur M.A., Sailah I., Syamsu K. and Y. Arkeman. 2007. Extraction of xylan from corncob. Indonesian Journal of Agricultural Postharvest Research, 4(1):38-43.

Sun Y. and Cheng, J. 2002. Hydrolysis of lignocellulosic material for ethanol production: a review. Bioresource Technology, 83:1-11.

Sunarti T.C. and N. Richana. 2008. Production of Trichoderma viride Cellulases from Corncob and its Cellulose Fraction. Indonesian Journal of Agricultural Postharvest Research, 4(1):38-43.

Taherzadeh M.J. 1999. Ethanol from Lignocellulose: Physiological Effects of Inhibitors and Fermentation Strategies. Ph.D. Tesis. Universitas Chalmers, Goteborg, Swedia.

Van Soest P.J. 1963. Use of Detergent in Analysis of Fibrous Feeds III. In M.L. Dreher (ed.). The Handbook of Dietary Fiber. New York, USA.

Xiang Q., Lee Y.Y., Pettersson P.O. and R.W. Torget. 2003. Heterogeneous Aspects of Acid Hydrolysis of $\alpha-$ cellulose. Applied. Biochemistry and Biotechnology, 105:505-514. 